\title{
What Are Universities Really For? Re-imagining Stewardship
}

\author{
Sara Black \\ https://orcid.org/0000-0003-2733-0504 \\ University of Johannesburg, South Africa \\ sara.black.za@gmail.com
}

What societies have wanted from their universities has been historically variable, internally contradictory, and only ever partly attainable. (Collini 2017, 17)

In July of 2021, an old "public" South African university announced the launch of a new private online high school. Although not the first time public South African universities had dabbled in private, for-profit activity, this particular example of overreach stimulated polarised debate across multiple channels, including an op-ed critique written by me published in the Daily Maverick (Black 2021).

However, much of the subsequent affirmation or opprobrium that op-ed attracted (and there was much of both) mistakes the specific example for a general problem. This essay attempts to expand the horizon of discussion to that general problem, namely, the state of higher education in South Africa in the contemporary moment and how we, as people who work in these institutions, understand our own role in affirming or challenging what universities are-descriptively and normatively-for.

To repeat Stefan Collini's $(2012,2017)$ enigmatic question: What are universities for? He slyly noted, "one begins to wonder whether societies do not make some kind of Faustian pact when they set up universities: they ask [universities] to serve various practical purposes, but if they are to be given the intellectual freedom necessary to serve those purposes properly, they will always tend to exceed or subvert those purposes" (2012, 25; italics added). The main "purposes" of which Collini speaks tend to coalesce around two primary axes: firstly, the production of future "skilled" workers; and secondly, scholarship towards enhancing humanity's understanding of itself and/in the world (which also includes the production of future "skilled" scholars).

The current concern is that the former crowds out the latter, and that the policy climate internationally encourages this in an instrumentalist sense. Universities are certainly-

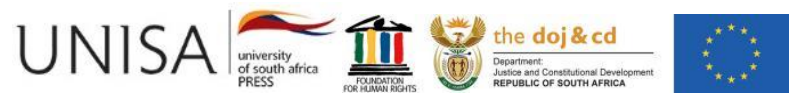

Education as Change

https://upjournals.co.za/index.php/EAC

Volume 25 | 2021 |\#10101| 7 pages

https://doi.org/10.25159/1947-9417/10101

ISSN 1947-9417 (Online)

(C) The Author(s) 2021 
at least currently - an apparatus of the contemporary "knowledge economy" wherein knowledge acquired is codified, certified and tradable on an increasingly globalised labour market for economic return. Such zero-sum knowledge-as-exchange-value depends on an inverse (and perverse) distribution of ignorance (Szkudlarek and Zamojski 2020), and is inevitably subject to the forces of any market, namely, the coercive laws of competition and falling rates of return on investment (aka "academic inflation"). Anyone who works in a university will recognise these trends: the increase in enrolment along with the decrease in the "value" of a degree; preference for commercially "high return on investment" degrees in commerce, law, science and technology, and the relations of competition between universities to attract what Stephen Ball $(1994,108)$ has called students who are "easy" to teach.

Yet to focus solely on this aspect of universities is reductionist. For they are also institutions of open-ended enquiry and emergence, resistance and inconvenient truths, creativity and exploration far beyond what can be rapidly turned over to technical Research and Development departments or patent registrars. Universities are not just production sites of knowledge-as-object (or students as object-holders), but also institutions that enable knowing-as-verb (Szkudlarek and Zamojski 2020), or what Heidegger (1968) distinguished as "thinking" rather than mere "calculating". Higher education institutions are, like basic education institutions, caught in a double-bind between "production" of graduates and patents and commodifiable discovery and "reproduction"- not just reproduction of thinking and open-ended enquiry, but the stewardship of the conditions required that this most human of practices may continue.

Concern for this role of stewardship of thinking beyond mere economic interest should not be mistaken for some kind of nostalgia; the story of universities is not one of decline ("Make Universities Great Again"). Rather, it is a story about the future-what kind of future we imagine for our institutions of higher education, and what threats we face in manifesting that future.

\section{Threats to Universities as Social Institutions of Non-Commodified Scholarship}

One threat universities face regarding their role as social institutions of scholarship in broader terms, I would argue, is our current obsession with the frame of "crisis". ${ }^{1}$ It is amnesiac and conservative (not to mention tinged with aforementioned nostalgia). The contradictions now biting universities - inadequate funding, increased pressure to massify and provide "access" (whatever that means-cf. Greene 2021), increased interference in research priorities and foci by policymakers and private donors alikedid not arrive like a bolt out of the blue. If we notice the history of universities and their social function, the "advanced neoliberal moment" under which we struggle is not a departure from the past, but a logical conclusion of it - what is constituting a sense of

Lauren Berlant (2011) astutely notes the use of the idea of "crisis" as a middle-class strategy for ahistoricising extant problems long in the making. 
"crisis" among academics and the academy is an uncomfortable confrontation with our own complicity and, as Collini puts it, "loss of nerve" $(2017,203)$ to overtly resist or imagine differently. Moreover, the "emergency" reactionism inherent in a response to a "crisis" privileges (re)action at the expense of careful analysis and strategy concerning what is to be done beyond hand-wringing. "Crisis" is a paralysing discourse, reducing responses to weak individualistic acts of defiance rather than coordinated efforts to refuse.

The second threat to our ability to imagine our future universities beyond extensions of what they currently are is a kind of schizophrenia wherein we believe we can somehow have "the best of both" - that somehow universities can be the darlings of private capital's insatiable techno-appetite and behave like profit-seeking enterprises, while also being autonomous places of thinking and questioning. This schizophrenia is exemplified in a recent op-ed by the vice-chancellor of another prominent South African university (Marwala 2021), which insists that universities are simultaneously to embrace logics and values of private enterprises and yet not. Such schizophrenia ignores the innate tendency for the pursuit of profit (or "savings", as it is framed in neoliberalised public institutions) to consume all else in its wake, a caution sounded by Rosa Luxemburg ([1913] 2016) over a hundred years ago.

Finally, a third threat to universities' continued ability to fulfil the social function of novel knowledge production beyond mere narrow economism is the myth of disinterest among academics. This myth persists in two forms: firstly, in the idea that noncommodified research is somehow "disinterested" and hence can claim a loftier moral righteousness; secondly, that academics seem to think themselves immune to the vicissitudes of broader society, given their somewhat removed position to pursue skholé (time free to think and dwell).

On the first form: whatever our foci of research (and teaching), we cannot, to paraphrase Sartre (1948), choose that which we do not believe to be better. Our interest might not be overtly economic, but it nonetheless exists (cf. Bourdieu 1988), and disavowing whatever interest motivates academics allows such interests to escape scrutiny or reflection. That is, rather than arguing for an ivory tower conception of "disinterest", we need to reclaim the concept of interest in social and humane terms from the economic definition that would subsume all others.

The second form of disinterest emanates from the conservative form of the firstnamely, that believing oneself to operate in a "disinterested" institution leads to the false assumption that the institution is not in the world and hence not subject to the problems of that world. Some naivete might have led scholars to not look up from their books and notice the library is (figuratively) burning. This second form of disinterest has perhaps, for some, meant that early warning signs have been ignored until the eleventh hour. 


\section{The South African Case}

The issues I have outlined here are not new insights; many before me have noticed and discussed them at length (e.g., Cribb and Gewirtz 2013; Sidhu 2006). But the South African higher education landscape, I would wager - in addition to struggling with these more general concerns - has some homegrown ones of its own.

The first is in how the structure of South African economic inequality, along with the distribution and form of economic activity, has placed higher education institutions as the vehicle of economic hope. The past 28 years of democracy have seen a lack of development in economic sectors that do not rely on university education (e.g., primary and manufacturing sectors), with growth confined to high-skill service industries (finance, for example) (see Allais 2020). In addition, the advent of democracy brought promises of access to previously out-of-reach institutions for most citizens of the country, expanding demand for places almost overnight. As a result, competition for university education is at fever pitch, and returns for those who succeed are generous (for now). Furthermore, given the economic conditions from which most South African tertiary students hail, it is unsurprising that fees have become a contentious fracture in the sector: most students cannot afford them, and most universities rely on them.

With a basic education system that continues to fail the majority of children who attend (roughly $20 \%$ of first graders get a shot at university at all), and a formal labour market unable to provide those who are not university-trained with a reasonable quality of life, it is unsurprising that reaching university is seen as the pinnacle of social achievement for many South Africans. Other routes to a sustainable and comfortable life are almost non-existent.

South African universities are thus tasked with making an unviable society viable (Fanon 2018) - a mandate they will inevitably fail to fulfil. Given this, it seems a fait accompli these institutions will be (eventually) deemed as freeloaders not meeting their end of an impossible social compact, and hence needing "discipline". As I wrote this essay, the committee chairperson of the South African Parliamentary Committee of Higher Education, Science and Technology called for public comment on the issue of "the relationship between institutional autonomy and public accountability", stating that there are "on-going concerns by various stakeholders regarding the use of institutional autonomy and an apparent resistance experienced by various stakeholders when state interventions are required" (PMG 2021). What is missing from this framing of the problem is a broader perspective of what South African universities are being asked to do, and the conditions under which they are being asked to do it.

In addition to the inordinate pressure on South African higher education institutions to miraculously transform the material conditions of the country (despite the failures of the systems upon which they depend), many are now also in need of cultural transformation in a moment of economic austerity. These two imperatives produce an unholy contradiction. That universities should be demographically reflective of the 
society they serve is necessary for their continued legitimacy, as well as to ensure pluralistic, robust scholarship and teaching. But to undertake this transformation just as budgets are slashed and admissions enlarged is to set up the incoming vanguard of young new academics to fail, irrespective of what they do. Inevitably, shallow racialised narratives will blame the degradation on the cultural rather than the economic, as is the wont in South African circles. In this way, incentives to circumvent austerity funding through seeking alternative (problematic) income streams become even stronger.

The sustenance of amnesia, schizophrenia, or faux disinterest cannot persist if the unique purpose of a public university - beyond being an extension of corporate research and development (R\&D) or secondary schooling - is to be retained. No amount of "relevance" through embracing the new fetish of the labour market (e.g., the so-called Fourth Industrial Revolution [4IR] and Artificial Intelligence [AI]), nor of sandbagging against the failures of other social systems (e.g., setting up a private feeder high school) will spare universities the exigencies they can now no longer ignore. Universities must somehow overcome their current tendency to behave in an individualistic manner and forge what Bourdieu called "collective intellectualism" towards a "scholarship of commitment" (Bourdieu 2003, 24), a scholarship that thinks forward in terms of systems, purpose and long-term public interest, rather than narrow economism or reactionary defensiveness. Such "collective" effort may very well include outright "refusal" to participate in the erosion of our public responsibility (Ball 2015).

This essay is not intended to be Cassandrist. There is much in our universities worth fighting for, and there are many who would take up cudgels for it. Such efforts are not motivated by a backward-looking revisionism, but by a hopeful future-oriented gaze; we may not yet know what knowledge we will produce in the future to the benefit of society, or yet how to imagine universities that minimise symbolic violence, even - dare we dream - exist outside class relations. What we do know is that such imagining and knowledge production cannot happen under the burgeoning market conditions under which we currently labour, and that the future university to which the next generation will look will be an impoverished one should we not "find our nerve" to insist there are alternatives. Whatever universities are for in any one time or place, they share one common purpose: the stewardship of institutional conditions to continue the pursuit of knowing-as-verb, asking new questions and re-asking old ones, free of narrow economism, coercion or threat, or any hegemonic episteme. In South Africa in particular, the protection of these conditions is all the more essential to forging pathways out of the tangled social problems we face.

Obsequious deference to market forces and New Managerialism is condescending to future generations, since we are essentially deciding they must accept a much narrower type of education than that which we ourselves enjoyed (Collini 2017). While universities have not always prioritised the public interest task of emergent, creative work, there are no other institutions that create these conditions. We should not abandon these sites, compromised and contradictory as they are, believing that ad hoc individual 
efforts or profit-driven private alternatives could suffice in their absence. To do so is to disavow our responsibility as public scholars to continuously wrestle with how we might best realise that fragile and tenacious ideal we call the public good.

\section{References}

Allais, S. 2020. “Skills for Industrialization in Sub-Saharan African Countries: Why Is Systemic Reform of Technical and Vocational Systems So Persistently Unsuccessful?" Journal of Vocational Education and Training 1-19. https://doi.org/10.1080/13636820.2020.1782455.

Ball, S. J. 1994. Education Reform: A Critical and Post-Structural Approach. Buckingham: Open University Press.

Ball, S. J. 2015. "What Is Policy? 21 Years Later: Reflections on the Possibilities of Policy Research". Discourse: Studies in the Cultural Politics of Education 36 (3): 306-13. https://doi.org/10.1080/01596306.2015.1015279.

Berlant, L. 2011. Cruel Optimism. Durham, NC: Duke University Press. https://doi.org/10.1515/9780822394716.

Bourdieu, P. 1988. Homo Academicus. Stanford, CA: Stanford University Press.

Bourdieu, P. 2003. Firing Back: Against the Tyranny of the Market 2. Translated by L. Wacquant. New York, NY: The New Press.

Black, S. 2021. "UCT Online High School: Reproducing Elites in a Sea of Inequality and Ignoring the Rest”. Daily Maverick, August 18, 2021. Accessed September 16, 2021. https://www.dailymaverick.co.za/opinionista/2021-08-18-uct-online-high-schoolreproducing-elites-in-a-sea-of-inequality-and-ignoring-the-rest/.

Collini, S. 2012. What Are Universities For? London: Penguin Books.

Collini, S. 2017. Speaking of Universities. New York, NY: Verso Books.

Cribb, A., and S. Gewirtz. 2013. "The Hollowed-Out University? A Critical Analysis of Changing Institutional and Academic Norms in UK Higher Education". Discourse: Studies in the Cultural Politics of Education 34 (3): 338-50. https://doi.org/10.1080/01596306.2012.717188.

Fanon, F. 2018. Alienation and Freedom. London: Bloomsbury Academic.

Greene, D. 2021. The Promise of Access: Technology, Inequality, and the Political Economy of Hope. Cambridge, MA: MIT Press. https://doi.org/10.7551/mitpress/11674.001.0001.

Heidegger, M. 1968. What Is Called Thinking? Translated J. G. Gray. New York, NY: Harper Perennial. 
Luxemburg, R. (1913) 2016. The Accumulation of Capital: A Contribution to the Economic Theory of Imperialism. Translated by N. Gray. In The Complete Work of Rosa Luxemburg Volume II: Economic Writings 2, edited P. Hudis and P. le Blanc, 1-342. London: Verso Books.

Marwala, T. 2021. "As Universities Remodel as Businesses, They Need to be Wary of Losing Core Mandates". Daily Maverick, September 5, 2021. Accessed September 16, 2021. https://www.dailymaverick.co.za/opinionista/2021-09-05-as-universities-remodel-asbusinesses-they-need-to-be-wary-of-losing-core-mandates/.

PMG (Parliamentary Monitoring Group). 2021. "Call for Comments: Institutional Autonomy of Public Higher Education Institutions". PMG, September 3, 2021. Accessed September 16, 2021. https://pmg.org.za/call-for-comment/1091/.

Sartre, J.-P. 1948. Existentialism and Humanism. London: Butler and Tanner.

Sidhu, R. K. 2006. Universities and Globalization: To Market, To Market. Mahwah, NJ: Lawrence Erlbaum Associates Publishers.

Szkudlarek, T., and P. Zamojski. 2020. "Education and Ignorance: Between the Noun of Knowledge and the Verb of Thinking". Studies in Philosophy and Education 39: 577-90. https://doi.org/10.1007/s11217-020-09718-9. 